\title{
PENERAPAN PENDEKATAN SAINTIFIK DALAM PEMBELAJARAN TEMATIK TERPADU
}

\author{
Oleh: \\ Drs. H. Moh. Masnun, M.Pd* \\ *Dosen Jurusan PGMI FITK IAIN Syekh Nurjati Cirebon \\ Email:pgmi@syekhnurjati.ac.id
}

\begin{abstract}
ABSTRAK
Kurikulum 2013 menganut pandangan dasar bahwa pengetahuan tidak dapat dipindahkan begitu saja dari guru ke peserta didik. Peserta didik adalah subjek yang memiliki kesempatan untuk secara aktif mencari, mengolah, mengonstruksi, dan menggunakan pengetahuan. Untuk itu pembelajaran harus berkenaan dengan kesempatan yang diberikan kepada peserta didik perlu didorong untuk bekerja memecahkan masalah, menemukan segala sesuatu untuk dirinya, dan berupaya keras mewujudkan ide-idenya.

Guru memberikan kemudahan untuk proses ini, dengan mengembangkan suasana belajar yang memberi kesempatan peserta didik untuk menemukan, menerapkan ide-ide mereka sendiri, menjadi dasar dan secara sadar menggunakan strategi mereka sendiri untuk belajar. Guru mengembangkan kesempatan belajar kepada peserta didik untuk meniti anak tangga yang membawa peserta didik kepemahaman yang lebih tinggi, yang semula ditentukan dengan bantuan guru tetapi semakin lama semakin mandiri. Bagi peserta didik pembelajaran harus bergeser dari "diberi tahu” menjadi aktif mencari tahu.
\end{abstract}

Keyword : Kurikulum 2013, Mandiri, Aktif

\section{A. PENDAHULUAN}

Sesuai dengan standar kompetensi lulusan yang akan dicapai sasaran pembelajaran mencakup pengembangan ranah sikap, pengetahuan dan keterampilan yang dielaborasi untuk setiap satuan pendidikan. Ketiga ranah kompetensi tersebut memiliki lintasan perolehan (proses psikologis) yang berbeda. Sikap perolehan melalui aktivitas "menerima, menjalankan, menghargai, menghayati, dan mengamalkan. Pengetahuan diperoleh melalui aktivitas, mengingat, memahami, menerapkan, menganalisis, mengevaluasi, mencipta". Keterampilan diperoleh melalui aktivitas, "mengamati, menanya, mencoba, menalar, menyaji, dan mencipta". 
Proses pembelajaran sepenuhnya diarahkan pada pengembangan ketiga ranah tersebut secara holistik, artinya pengembangan ranah yang satu tidak bisa dipisahkan dengan ranah lainnya. Dengan demikian proses pembelajaran secara utuh melahirkan kualitas pribadi yang mencerminkan keutuhan penguasaan sikap, pengetahuan dan keterampilan.

Apabila dihubungkan dengan belajar mengajar pendekatan bias diartikan sebagai pola-pola umum kegiatan guru-anak didik dalam perwujudan kegiatan belajar mengajar untuk mencapai tujuan yang telah digariskan. (Djamarah, 2006 : 1) Kemp dalam Sanjaya (2006 : 126) menjelaskan bahwa pendekatan pembelajaran adalah suatu kegiatan pembelajaran yang harus dikerjakan guru dan siswa agar tujuan pembelajaran dapat dicapai secara efektif dan efisien. Menurut Hamzah B. Uno (2008 :3) Pendekatan pembelajaran adalah cara-cara yang akan digunakan oleh pengajar untuk memilih kegiatan belajar yang akan digunakan dalam proses pembelajaran. Pemilihan kegiatan belajar tersebut dilakukan dengan mempertimbangkan situasi dan kondisi, sumber belajar, kebutuhan dan karakteristik peserta didik yang dihadapi dalam rangka mencapai tujuan pembelajaran tertentu. Jadi strategi pembelajaran merupakan cara-cara yang dikemas oleh seorang guru dalam pembelajaran dengan mempersiapkan segala sesuatu yang dapat mendukung keberhasilan tujuan pembelajaran dengan efektif dan efisien.

\section{B. PEMBAHASAN}

\section{1) Pengertian Pendekatan Saintifik}

Pendekatan saintifik adalah konsep dasar yang mewadahi, menginspirasi, menguatkan, dan melatari pemikiran tentang bagaimana metode pembelajaran diterapkan berdasarkan teori tertentu. Kemendikbud (2013) memberikan konsepsi tersendiri bahwa pendekatan ilmiah (scientific approach) dalam pembelajaran di dalamnya mencakup komponen: mengamati, menanya, mencoba/ menggali informasi/eksperimen, menalar/ mengasiasikan /mengolah informasi, menyajikan/mengkomunikasikan.

Peserta didik diarahkan untuk menemukan sendiri berbagai fakta, membangun konsep dan nilai-nilai baru yang diperlukan untuk kehidupannya. Fokus proses pembelajaran diarahkan pada pengembangan keterampilan siswa 
dalam memproseskan pengetahuan, menemukan dan mengembangkan sendiri fakta, konsep dan nilai-nilai yang diperlukan. (Mulyasa : 2005)

Pendekatan saintifik memuat kriteria-kriteria berikut.

a. Materi pembelajaran berbasis pada fakta atau fenomena yang dapat dijelaskandengan logika atau penalaran tertentu; bukan sebatas hanya kirakira, khayalan,legenda, atau dongeng semata

b. Penjelasan guru, respon siswa, dan interaksi edukatif guru-siswa terbebas dari prasangka yang serta-mert, pemikiran subjektif, atau penalaran yang menyimpangdari alur berpikir logis

c. Mendorong dan menginspirasi siswa berpikir secara kritis, analistis, dan tepatdalam mengidentifikasi, memahami, memecahkan masalah, dan mengaplikasikanmateri pembelajaran

d. Mendorong dan menginspirasi siswa mampu berpikir hipotetik dalam melihat perbedaan, kesamaan, dan tautan satu sama lain dari materi pembelajaran.

e. Mendorong dan menginspirasi siswa mampu memahami, menerapkan, danmengembangkan pola berpikir yang rasional dan objektif dalam merespons materi pembelajaran

f. Berbasis pada konsep, teori, dan fakta empiris yang dapat dipertanggung jawabkan

g. Tujuan pembelajaran dirumuskan secara sederhana dan jelas, namun menariksistem penyajiannya.

Kurikulum 2013 mengembangkan dua modus proses pembelajaran yaitu proses pembelajaran langsung dan proses pembelajaran tidak langsung. Proses pembelajaran langsung adalah proses pendidikan di mana peserta didik mengembangkan pengetahuan, kemampuan berpikir dan keterampilan psikomotorik melalui interaksi langsung dengan sumber belajar yang dirancang dalam silabus dari RPP berupa kegiatan-kegiatan pembelajaran.

Dalam pembelajaran langsung tersebut peserta didik melakukan kegiatan belajar mengamati, menanya, mengumpulkan informasi, mengasosiasi atau menganalisis, dan mengekomunikasikan apa yang sudah ditemukannya dalam 
kegiatan analisis. Proses pembelajaran langsung menghasilkan pengetahuan dan keterampilan langsung atau yang disebut dengan instructional effect.

Pembelajaran tidak langsung adalah proses pendidikan yang terjadi selama proses pembelajaran langsung, tetapi tidak dirancang dalam kegiatan khusus. Pembelajaran tidak langsung berkenaan dengan pengembangan nilai dan sikap. Berbeda dengan pengetahuan tentang nilai dan sikap yang dilakukan dalam proses pembelajaran langsung oleh mata pelajaran tertentu, pengembangan sikap sebagai proses pengembangan moral dan perilaku dilakukan oleh seluruh mata pelajaran dan dalam setiap kegiatan yang terjadi di kelas sekolah dan masyarakat.

Oleh karena itu, dalam proses pembelajaran kurikulum 2013, semua kegiatan yang terjadi selama belajar di sekolah dan di luar dalam kegiatan kokurikuler dan ekstrakurikuler terjadi proses pembelajaran untuk mengembangkan moral dan perilaku yang terkait dengan sikap.

Baik pembelajaran langsung maupun pembelajaran tidak langsung dilaksanakan secara terintegrasi dan tidak terpisah.Pembelajaran langsung berkenaan dengan pembelajaran yang menyangkut kompetensi dasar yang dikembangkan dari kompetensi inti 3 (kompetensi pengetahuan), dan kompetensi inti 4 (kompetensi keterampilan).Pembelajaran tidak langsung berkenaan dengan pembelajaran yang menyangkut kompetensi dasar yang dikembangkan dari kompetensi inti-1 (Kompetensi spiritual) dan kompetensi inti-2 (kompetensi sosial). Keduanya, dikembangkan secara bersamaan dalam suatu proses pembelajaran dan menjadi wahana untuk mengembangkan kompetensi dasar.

\section{2) Penerapan Pendekatan Saintifik dalam Pembelajaran Tematik Terpadu}

\section{Mengamati}

Kegiatan belajar yang dilakukan dalam proses mengamati adalah membaca, mendengar, menyimak, melihat (tanpa atau dengan alat),.Kompetensi yang dikembangkan adalah melatih kesungguhan, ketelitian, mencari informasi.

Metode mengamati mengutamakan, kebermaknaan proses pembelajaran (meaningfull learning). Metode ini memiliki keunggulan 
tertentu, seperti menyajikan media objek secara nyata, peserta didik senang dan tertantang, dan mudah pelaksanaannya. Tentu saja kegiatan mengamati dalam rangka pembelajaran ini biasanya memerlukan waktu persiapan yang lama dan matang, biaya dan tenaga relative banyak, dan jika tidak terkendali akan mengaburkan makna serta tujuan pembelajaran.

Metode mengamati sangat bermanfaat bagi pemenuhan rasa ingin tahu peserta didik sehingga proses pembelajaran memiliki kebermaknaan yang tinggi. Dengan metode observasi peserta didik menemukan fakta bahwa ada hubungan antara objek yang dianalisis dengan materi pembelajaran yang digunakan oleh guru.

Kegiatan mengamati dalam pembelajaran dilakukan dengan menempuh langkah-langkah berikut ini :

a. Menentukan objek apa yang akan diobservasi

b. Membuat pedoman observasi sesuai dengan lingkup objek yang akan observasi.

c. Menentukan secara jelas data-data apa yang perlu diobservasi, baik primer maupun sekunder

d. Menentukan di mana tempat objek observasi

e. Menentukan secara jelas bagaimana observasi akan dilakukan untuk mengumpulkan data agar berjalan mudah dan lancar

f. Menentukan cara dan melakukan pencatatan atas hasil observasi, seperti menggunakan buku catatan, kamera, tape recorder, video perekam, dan alatalat tulis lainnya.

Praktik observasi dalam pembelajaran akan lebih optimal jika peserta didik dan guru melengkapi diri dengan alat-alat pencatatan dan alatalat lain, seperti (1) tape recorder, untuk merekam pembicaraan; (2) kamera, untuk merekam objek atau kegiatan secara visual; (3) film atau video, untuk merekam kegiatan objek atau secara audio visual, dan (4) alat-alat lain sesuai dengan keperluan.

Secara lebih luas alat atau instrument yang digunakan dalam melakukan observasi dapat berupa daftar cek (checklist) skala rentang (rating scale), catatan berkala, dan alat mekanikal (mechanical device) 
daftar cakapan berupa suatu daftar yang berisikan nama-nama subjek, objek atau faktor-faktor yang akan diobservasi skala rentang, berupa alat untuk mencatat gejala atau fenomena menurut tingkatannya. Catatan anecdotal berupa catatan yang dibuat oleh peserta didik dan guru mengenai kelakuankelakuan luar biasa yang ditampilkan oleh subjek atau objek yang diobservasi.

Berikut contoh tema 3 kegiatanku pada subtema 1 kegiatan siang hari.Peserta didik diajak mengamati gambar kemudian mereka diajak mengidentifikasi tentang seorang kakak dan adik membaca buku di rumah. Dengan mengamati gambar, peserta didik akan dapat secara langsung dapat menceritakan kondisi sebagaimana yang dituntut dalam kompetensi dasar dan indikator.

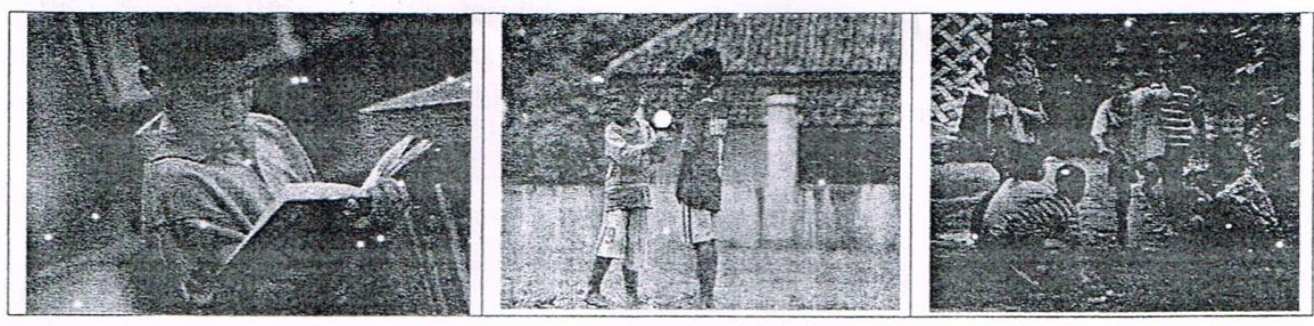

Contoh Objek Gambar yang diamati Siswa

Pengamatan gambar dapat dikembangkan dan dikaitkan dengan pengetahuhan awal dari siswa sehingga proses pembelajaran dapat lebih menyenangkan dan membangkitkan rasa antusias siswa karena dapat mengaitkan pengalaman belajarnya dengan kehidupan nyata. Gambargambar yang diamati juga harus bervariasi dan dapat membangkitkan keingintahuan anak sehingga dapat memancing anak untuk bertanya hal-hal yang ingin diketahui dengan rasa ingin tahu yang tinggi.

\section{Menanya}

Kegiatan belajar menanya dilakukan dengan cara mengajukan pertanyaan tentang informasi yang tidak dipahami dari apa yang diamati atau pertanyaan untuk mendapatkan informasi tambahan tentang apa yang diamati (dimulai dari pertanyaan factual sampai ke pertanyaan yang bersifat hipotetik). Kompetensi yang dikembangkan adalah mengembangkan kreativitas rasa ingin tahu, kemampuan merumuskan pertanyaan untuk 
membentuk pikiran kritis yang perlu untuk hidup cerdas dan belajar sepanjang hayat.

Istilah "pertanyaan" tidak selalu dalam bentuk "kalimat tanya", melainkan juga dalam bentuk pertanyaan, asalkan keduanya menginginkan tanggapan verbal. Bentuk pertanyaan misalnya: Apakah ciri-ciri kalimat yang efektif? Bentuk pernyataan, misalnya : Sebutkan ciri-ciri kalimat efektif!.

a. Fungsi bertanya

1) Membangkitkan rasa ingin tahu, minat, dan perhatian peserta didik tentang suatu tema atau topik pembelajaran.

2) Mendorong dan menginspirasi peserta didik untuk aktif belajar, serta mengembangkan pertanyaan dari dan untuk dirinya sendiri.

3) Mendiagnosis kesulitan belajar peserta didik sekaligus menyampaikan ancangan untuk mencari solusinya.

4) Menstrukturkan tugas-tugas dan memberikan kesempatan kepada peserta didik untuk menunjukkan sikap, keterampilan, dan pemahamannya atas substansi pembelajaran yang diberikan.

5) Membangkitkan keterampilan peserta didik dalam berbicara, mengajukan pertanyaan, dan memberi jawaban secara logis, sistematis, dan menggunakan bahasa yang baik dan benar.

6) Mendorong partisipasi peserta didik dalam berdiskusi, berargumen, mengembangkan kemampuan berpikir, dan menarik simpulan.

7) Membangun sikap keterbukaan untuk saling memberi dan menerima pendapat atau gagasan, memperkaya kosa kata, serta mengembangkan toleransi sosial dalam hidup berkelompok.

8) Membiasakan peserta didik berpikir spontan dan cepat, serta sigap dalam merespon persoalan yang tiba-tiba muncul.

9) Melatih kesantunan dalam berbicara dan membangkitkan kemampuan berempati satu sama lain.

Pada saat siswa mengamati dan menjawab pertanyaan guru, maka sudah memadukan dan mengakomadasi mata pelajaran Bahasa Indonesia, (untuk aspek mendengarkan, dan berbicaranya, membaca 
gambar serta menulis hasil identifikasi kerukunan di rumah) sehingga dari hasil pengamatan dan menanya diharapkan ada jawaban yang ilmiah dan memberikan pemahaman yang baik pada siswa.

\section{Mengumpulkan Informasi / Eksperimen (Mencoba)}

Mengumpulkan informasi/ eksperimen kegiatan pembelajarannya antara lain melakukan eksperimen, membaca sumber lain selain buku teks; mengamati objek/ kejadian/ aktivitas, dan wawancara dengan narasumber. Kompetensi yang dikembangkan dalam proses mengumpulkan informasi/ eksperimen adalah mengembangkan sikap teliti, jujur, sopan, menghargai pendapat orang lain, kemampuan berkomunikasi, menerapkan kemampuan mengumpulkan informasi melalui berbagai cara yang dipelajari, mengembangkan kebiasaan belajar dan belajar sepanjang hayat.

Untuk memperoleh hasil belajar yang nyata atau autentik, peserta didik harus mencoba atau melakukan percobaan, terutama untuk materi atau substansi yang sesuai. Peserta didik pun harus memiliki keterampilan proses untuk mengembangkan pengetahuan tentang alam sekitar, serta mampu menggunakan proses ilmiah dan bersikap ilmiah dan bersikap ilmiah untuk memecahkan masalah-masalah yang dihadapinya sehari-hari.

Agar pelaksanaan percobaan dapat berjalan lancer (1) Guru hendaknya merumuskan tujuan eksperimen yang akan dilaksanakan murid. (2) Guru bersama murid mempersiapkan perlengkapan yang dipergunakan. (3) Perlu memperhitungkan tempat dan waktu. (4) Guru menyediakan kertas kerja untuk pengarahan kegiatan murid. (5) Guru membicarakan masalah yang akan yang akan dijadikan eksperimen, (6) Membagi kertas kerja kepada murid, (7) Murid melaksanakan eksperimen dengan bimbingan guru, dan (8) Guru mengumpulkan hasil kerja murid dan mengevaluasinya, bila dianggap perlu didiskusikan secara klasikal.

Untuk memperoleh hasil belajar yang nyata atau autentik, peserta didik harus mencoba atau melakukan eksperimen, terutama untuk materi atau substansi yang sesuai pada tema 3 kelas 1 ini misalnya, peserta didik harus memahami perbedaan siang dan malam dengan melakukan percobaan sederhana. 


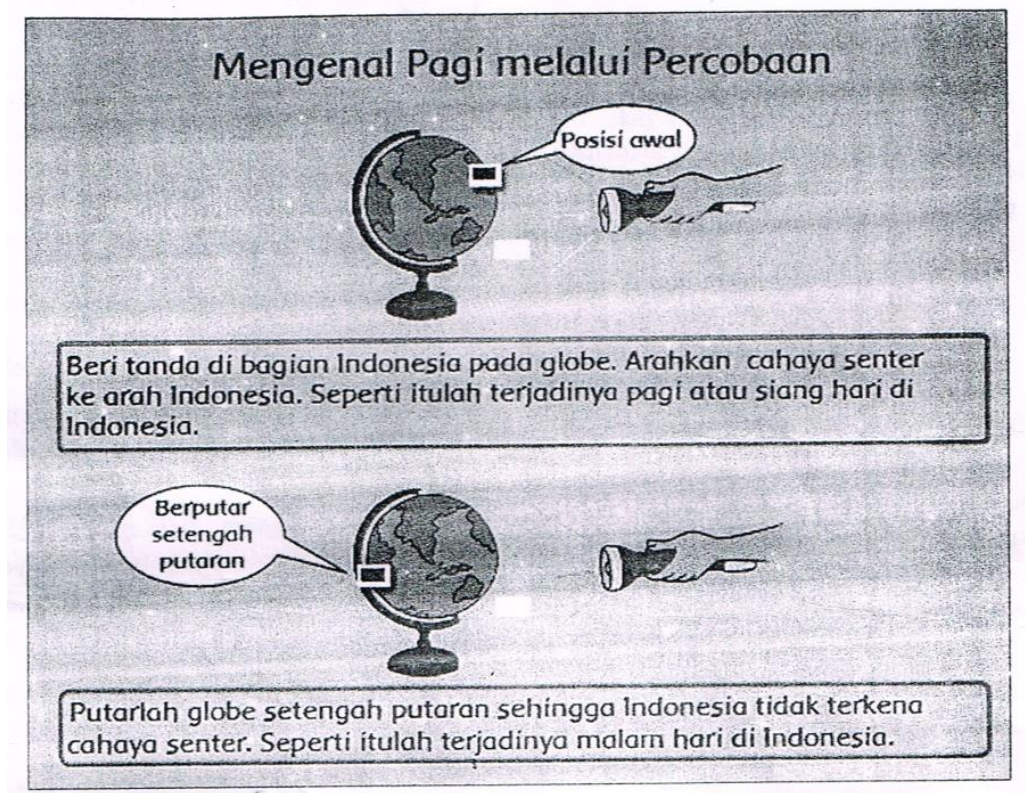

\section{Menganalisis / Mengolah Informasi}

Kegiatan belajar yang dilakukan dengan proses mengasosiasi/ mengolah informasi adalah sebagai berikut :

a. Mengolah informasi yang sudah dikumpulkan baik terbatas dari hasil kegiatan mengumpulkan/ eksperimen maupun hasil dari kegiatan mengamati dan kegiatan mengumpulkan informasi.

b. Pengolahan informasi yang dikumpulkan dari yang bersifat menambah keluasan dan kedalaman sampai kepada pengolahan informasi yang bersifat mencari solusi dari berbagai sumber yang memiliki pendapat yang berbeda sampai kepada yang bertentangan.

Kompetensi yang dikembangkan dalam proses mengasosiasi/ mengolah informasi adalah mengembangkan sikap jujur, teliti, disiplin, taat aturan, kerja keras, kemampuan menerapkan prosedur dan kemampuan berpikir induktif serta deduktif dalam menyimpulkan.

Dalam kegiatan mengasosiasi/ mengolah informasi terdapat kegiatan menalar. Istilah "menalar" dalam kerangka proses pembelajaran dengan pendekatan ilmiah yang dianut dalam Kurikulum 2013 untuk menggambarkan bahwa guru dan peserta didik merupakan pelaku aktif. Titik tekannya tentu dalam banyak hal dan situasi peserta didik harus lebih aktif daripada guru. Penalaran adalah proses berpikir yang logis dan sistematis 
atas fakta-fakta empiris yang dapat diobservasi untuk memperoleh simpulan berupa pengetahuan.

Penalaran dimaksud merupakan penalaran ilmiah, penalaran nonilmiah tidak selalu tidak bermanfaat.Istilah menalar di sini merupakan pedoman dari associating; bukan merupakan terjemahan dari reasoning, meski istilah ini juga bermakna menalar atau penalaran.Karena itu, istilah aktivitas menalar dalam konteks pembelajaran pada kurikulum 2013 dengan pendekatan ilmiah banyak pembelajaran merujuk pada kemampuan mengelompokkan beragam ide dan mengasosiasikan beragam peristiwa untuk kemudian memasukkannya menjadi penggalan memori.

Bagaimana aplikasinya dalam proses pembelajaran? Aplikasi pengembangan aktivitas pembelajaran untuk meningkatkan daya menalar peserta didik dapat dilakukan dengan cara berikut ini.

1) Guru menyusun bahan pembelajaran dalam bentuk yang sudah siap sesuai dengan tuntutan kurikulum.

2) Guru tidak banyak menerapkan metode ceramah atau metode kuliah. Tugas utama guru adalah memberi instruksi singkat tapi jelas dengan disertai contoh-contoh, baik dilakukan sendiri maupun dengan cara simulasi.

3) Bahan pembelajaran disusun secara berjenjang atau hierarkis, dimulai dari yang sederhana (persyaratan rendah) sampai pada yang kompleks (persyaratan tinggi)

4) Kegiatan pembelajaran berorientasi pada hasil yang dapat diukur dan diamati.

5) Setiap kesalahan harus segera dikoreksi atau diperbaiki.

6) Perlu dilakukan pengulangan dan latihan agar perilaku yang diinginkan dapat menjadi kebiasaan atau pelaziman.

7) Evaluasi atau penilaian didasari atas perilaku yang nyata atau otentik.

8) Guru mencatat semua kemajuan peserta didik untuk kemungkinan memberikan tindakan pembelajaran perbaikan. 
Proses menalar juga bisa diasah dengan dorongan guru dalam bertanya jawab dan memancing siswa untuk berpikir komplek misalnya seperti saat guru dan siswa membahas masalah anak belajar, anak bermain, masyarakat membersihkan lingkungan bersama-sama dan sebagainya di suatu tempat dimana mereka dapat mengamati. Akan lebih bermakna proses pembelajarannya jika siswa dapat langsung mencoba

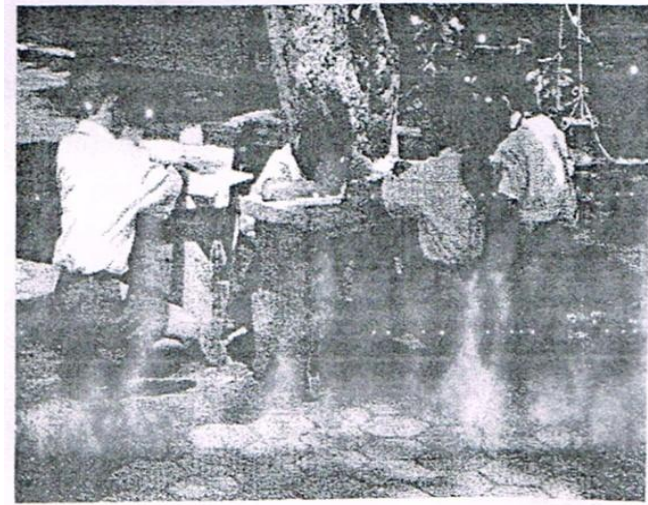
melakukan apa yang diamati, ditanyakan dan dinalar secara ilmiah dalam tindakan nyata. Pada tahapan mengolah ini juga peserta didik sedapat mungkin dikondisikan belajar secara kolaboratif.

Pada pembelajaran kolaboratif kewenangan guru fungsi guru lebih bersifat direktif atau manajer belajar, sebaliknya peserta didiklah yag harus lebih aktif. Jika pembelajaran kolaboraltif diposisikan sebagai satu falsafah pribadi, maka ia menyentuh tentang identitas peserta didik terutama jika mereka berhubungan atau berinteraksi dengan yang lain atau guru. Dalam situasi kolaboratif itu, peserta didik berinteraksi dengan empati, saling menghormati, dan menerima kekurangan atau kelebihan masing-masing. Dengan cara semacam ini akan tumbuh rasa aman, sehingga memungkinkan peserta didik menghadapi aneka perubahan dan tuntutan belajar secara bersama-sama. Peserta didik secara bersama-sama, saling bekerjasama, saling membantu mengerjakan hasil tugas terkait dengan materi yang sedang dipelajari.

\section{Mengkomunikasikan}

Kegiatan belajar mengajar mengkomunikasikan adalah menyampaikan hasil pengamatan, kesimpulan berdasarkan hasil analisis secara lisan, tertulis, atau media lainnya.Kompetensi yang dikembangkan dalam tahapan mengkomunikasikan adalah mengembangan sikap jujur, 
teliti, toleransi, kemampuan berpikir sistematis, mengungkapkan pendapat dengan singkat dan jelas, dan mengembangkan kemampuan berbahasa yang baik dan benar.

Kegiatan menyimpulkan merupakan kelanjutan dari kegiatan mengolah, bisa dilakukan bersama-sama dalam satu kesatuan kelompok atau bisa juga dengan dikerjakan sendiri setelah mendengarkan hasil kegiatan mengolah informasi.Hasil tugas yang dikerjakan bersama dalam satu kelompok kemudian dipresentasikan atau dilaporkan kepada guru. Kegiatan ini sekaligus merupakan kesempatan bagi guru untuk melakukan konfirmasi terjadap apa yang telah disimpulkan oleh siswa.

Hasil tugas yang telah dikerjakan bersama-sama secara kolaboratif dapat disajikan dalam bentuk laporan tertulis dan dapat dijadikan sebagai salah satu bahan untuk portofolio kelompok dan atau individu, yang sebelumnya di konsultasikan terlebih dulu kepada guru. Pada tahapan ini kendatipun tugas dikerjakan secara berkelompok, tetapi sebaiknya hasil pencatatan dilakukan oleh masing-masing individu sehingga portofolio yang dimasukkan ke dalam file atau map peserta didik terisi dari hasil pekerjaannya sendiri secara individu.

\section{Contoh penerapan project based learning sederhana di SD Kelas 1}

\section{Tema : Kegiatanku}

\section{Subtema : Kegiatan Pagi Hari}

Saat siswa belajar tentang tema kegiatanku sub tema Kegiatan di Pagi Hari, ada kompetensi Dasar Bahasa Indonesia yang harus dikuasi yaitu "Mengenal teks deskriptif tentang anggota tubuh dan panca indra, wujud, dan sifat benda, serta peristiwa siang dan malam dengan bantuan guru atau teman dalam bahasa Indonesia lisan atau tulis yang dapat diisi dengan kosa kata bahasa daerah untuk membantu pemahaman”. Maka untuk memahami kompetensi tersebut dapat diterapkan model Discovery learning sederhana seperti berikut:

\section{Peran Guru:}

1. Instruksikan dan berikan waktu yang cukup pada siswa untuk membawa atau menyiapkan media jelasnya berupa gambar suasana pagi hari, Globe atau 
bisa digantikan dengan bola, senter, dan buku siswa (semua media dapat disediakan oleh guru)

2. Guru menyampaikan pemahaman bahwa matahari menyinari bumi serta memberikan cahaya dan panas bagi bumi

3. Bimbing siswa untuk memunculkan pertanyaan tentang perubahan dari siang menjadi malam.

4. Siswa dibagi ke dalam beberapa kelompok. Secara bergantian melakukan percobaan agar siswa dapat menemukan hal-hal yang terjadi pada saat melakukan percobaan beri siswa motivasi untuk cermat dalam melakukan percobaan.

\section{Peran Siswa:}

1. Siswa mengamati gambar yang disajikan guru dan menjawab pertanyaan tentang suasana pagi hari.

2. Siswa menjawab pertanyaan guru tentang dari mana bumi menerima cahaya sehingga menjadi terang.

3. Siswa secara berkelmpok melakukan percobaan menggunakan globe atau bola, senter dan untuk melihat peristiwa terjadi siang dan malam.

4. Siswa dengan bimbingan guru melakukan eksplorasi percobaan secara menyeluruh dengan memanfaatkan media secara maksimal.

\section{Aktivitas Pertama}

1. Siswa mengamati dan menyebutkan tanda-tanda siang hari dan malam hari.

2. Siswa menyebutkan sebab-sebab terjadinya siang dan malam.

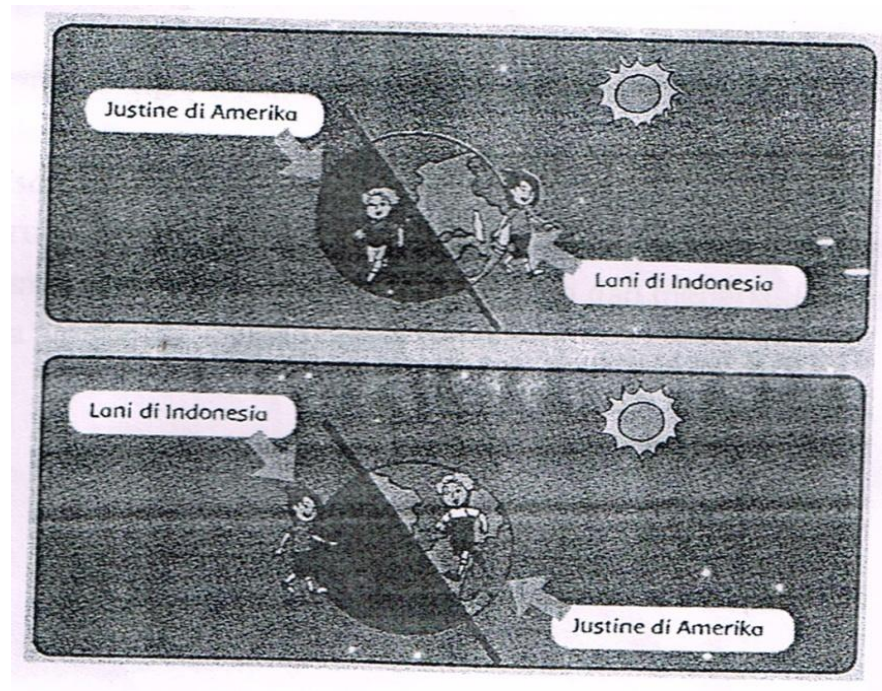


3. Setelah melakukan kegiatan siswa dibimbing untuk menjawab pertanyaanpertanyaan mengenai hal-hal berikut:

a. Dimana gambar matahari ?

b. Dimana posisi Lani ?

c. Dimana posisi Justine ?

\section{Aktivitas Kedua}

Mengenai Pagi melalui Percobaan

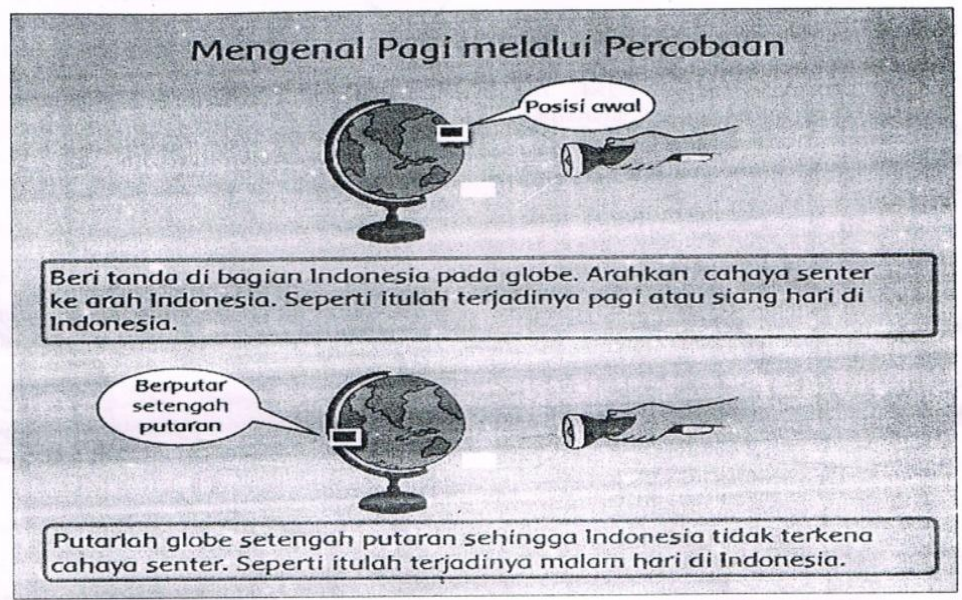

Apabila guru membimbing dengan tepat maka dengan media yang disediakan seperti di atas dan mempraktikkannya dengan benar bermakna guru telah melaksanakan model pembelajaran discovery learning sesuai dengan teori yang telah dipaparkan sebelumnya. Dalam hal ini guru bias mengaplikasikan model-model tersebut di atas pada tema-tema yang lain sehingga membuat pembelajaran lebih bermakna dan menarik. Proses penilaian dapat dilakukan selama guru mendampingi siswa beraktivitas. 


\section{3) Contoh Rencana Pelaksanaan Pembelajaran dengan Pendekatan} Saintifik

\section{RENCANA PELAKSANAAN PEMBELAJARAN}

(RPP)

$\begin{array}{ll}\text { Satuan Pendidikan } & : \text { MI } \\ \text { Kelas / Semester } & : 1 / 2 \text { (Dua) } \\ \text { Tema / Subtema } & : \text { Pengalamanku / Pengalaman Masa Kecil } \\ \text { Alokasi Waktu } & : 1 \text { x Pertemuan ( } 5 \text { x } 35 \text { Menit })\end{array}$

\section{A. Kompetensi Inti (KI)}

1. Menerima dan menjalankan ajaran agama yang dianutnya.

2. Memiliki perilaku jujur, disiplin, tanggung jawab, santun, peduli dan percaya diri dalam berinteraksi dengan keluarga, teman dan guru

3. Memahami pengetahuan faktual dengan cara mengamati (mendengar, melihat, membaca) dan menanya berdasarkan rasa ingin tahu tentang dirinya, mahluk ciptaan Tuhan dan kegiatannya, dan benda-bendanya yang dijumpainya di rumah dan di sekolah.

4. Menyajikan pengetahuan faktual dalam bahasa yang jelas dan logis, dalam karya yang estetis, dalama gerakan yang mencerminkan anak sehat, dan dalam tindakan yang mencerminkan perilaku anak beriman dan berakhlak mulia.

\section{B. Kompetensi Dasar (KD) dan Indikator}

\section{Bahasa Indonesia}

\section{Kompetensi Dasar}

1.1 Menerima anugerah Tuhan Yang Maha Esa berupa bahasa Indonesia yang dinekal sebagai bahasa persatuan dan sarana belajar di tengah keberagaman bahasa daerah.

1.1 Memiliki kepedulian dan rasa ingin tahu terhadap keberadaan wujud dan sifat benda melalui pemanfaatan bahasa Indonesia dan/atau bahasa daerah.

3.4 Mengenai teks cerita diri/ personal tentang keberadaan keluarga dengan bantuan guru atau teman dalam bahasa Indonesia lisan dan 
tulis yang dapat diisi dengan kosakata bahasa daerah untuk membantu pemahaman.

4.4 Menyampaikan teks cerita diri/ personal tentang keluarga secara mandiri dalam bahasa Indonesia lisan dan tulis yang dapat diisi dengan kosakata bahasa daerah untuk membantu penyajian.

\section{Indikator:}

3.4.1 Menyebutkan peristiwa masa kecil dalam bahasa Indonesia lain.

3.4.2 Menceritakan secara lisan peristiwa masa kecil yang diingatnya.

4.4.1 Menulis kalimat sederhana tentang cerita diri/ personel dengan bahasa Indonesia tulis yang sederhana.

\section{PPkn}

\section{Kompetensi Dasar:}

1.2 Menerima kebersamaan dalam keberagaman sebagai anugerah Tuhan Yang Maha Esa di lingkungan rumah dan sekolah.

2.1 Menunjukkan perilaku jujur, disiplin, tanggung jawab, santun, peduli dan percaya diri dalam berinteraksi dengan keluarga, teman, dan guru sebagai perwujudan nilai dan moral Pancasila.

3.1 Mengenal simbol-simbol sila Pancasila dalam lambang Negara "Garuda Pancasila"

4.1 Mengamati dan menceritakan perilaku di sekitar rumah dan sekolah dan mengaitkannya dengan pengenalannya terhadap salah satu simbol sila Pancasila dalam lambang Negara "Garuda Pancasila".

\section{Indikator :}

3.1.1 Menyebutkan lambang Negara "Garuda Pancasila"

3.1.2 Membedakan simbol-simbol lambang Negara "Garuda Pancasila"

3.1.3 Memasangkan simbol-simbol lambang Negara "Garuda Pancasila"

4.1.1 Menceritakan secara lisan makna simbol-simbol lambang Negara "Garuda Pancasila"

4.1.2 Menampilkan perilaku sehari-hari di sekitar sekolah yang sesuai dengan sila-sila pada Pancasila. 


\section{Seni Budaya dan Prakarya (SBDP)}

\section{Kompetensi Dasar:}

1.1 Merasakan keindahan alam sebagai salah satu tanda-tanda kekuasaan Tuhan.

2.1 Menunjukkan rasa percaya diri untuk berlatih mengekspresikan diri dalam mengolah karya seni.

3.2 Mengenal pola irama lagu bervariasi menggunakan alat musik ritmis.

4.8 Memainkan pola irama lagu bertanda berirama dua dan tiga dengan alat musik ritmis.

\section{Tujuan Pembelajaran}

1. Dengan menirukan guru menyanyikan lagu "Bunda Piara" siswa dapat menyebutkan pengalaman masa kecil dalam bahasa Indonesia lisan dengan percaya diri.

2. Dengan menyebutkan peristiwa masa kecil yang diingat, siswa dapat menceritakan pengelamannya sendiri dengan percaya diri dan bahasa yang santun.

3. Dengan menceritakan pengalaman sendiri, siswa dapat menulis cerita diri/ personal dengan EYD yang benar.

4. Dengan mengamati gambar siswa dapat mengidentifikasi lambang negara "Garuda Pancasila" dengan percaya diri.

5. Tanpa membuka buku, siswa dapat menyebutkan simbol-simbol sila Pancasila lambang "Garuda Pancasila" dengan percaya diri.

6. Dengan mengamati gambar, siswa dapat memasanglan simbol-simbol sila Pancasila lambang negara "Garuda Pancasila" dengan percaya diri

7. Setelah memasangkan simbol-simbol lambang negara Pancasila dengan penuh tanggung jawab.

8. Dengan menceritakan makna simbol-simbol lambang negara Pancasila, siswa dapat menampilkan perilaku sehari-hari di sekitar sekolah sesuai dengan sila Pancasila dengan percaya diri.

9. Dengan mendengarkan lagu Hari Merdeka, siswa dapat menirukan pola irama lagu bervariasi menggunakan alat music ritmis dengan percaya diri. 
10. Dengan menirukan, siswa dapat membedakan pola irama lagu bervariasi dengan berani.

11. Setelah membedakan pola irama lagu bervariasi, siswa dapat mengikuti irama lagu bertanda berirama dua dengan berani.

12. Dengan mengikuti irama lagu bertanda berirama dua, siswa dapat menggunakan alat musik ritmis dengan berani.

\section{Materi Pembelajaran}

1. Pengalaman diri waktu kecil (Buku siswa halaman 1-3)

2. Simbol-simbol Pancasila (Buku siswa halam 4-6)

3. Pola irama lagu menggunakan alat musik ritmis (Buku siswa hal 7)

\section{E. Metode dan Pendekatan Pembelajaran}

Metode (ceramah, diskusi, dan tanya jawab)

Pendekatan saintifik (mengamati, menanya, mengumpulkan informasi/ eksperimen, mengasosiasi/ menalar, dan mengkomunikasikan)

\section{F. Media, Alat dan Sumber Pelajaran}

1. Media : Lagu Bunda Piara dan "Hari Merdeka" gambar burung Garuda Pancasila, 10 set kartu bergambar simbol-simbol dari Pancasila, gambar-gambar berbagai alat music.

2. Alat/ bahan : Alat musik ritmis

3. Sumber belajar:

Kurnianingsih, Yanti dkk. 2013. Buku Siswa Tema 5 Pengalamanku. Buku Tematik Terpadu Kurikulum 2013. Jakarta : Kementerian Pendidikan dan Kebudayaan.

\section{G. Langkah-langkah Kegiatan Pembelajaran}

\begin{tabular}{|c|c|c|}
\hline Kegiatan & Deskripsi Kegiatan & $\begin{array}{c}\text { Alokasi } \\
\text { Waktu }\end{array}$ \\
\hline Pendahuluan & 1. Guru membuka pelajaran dengan menyapa & 15 menit \\
& siswa dan menanyakan kabar mereka & \\
& 2. Guru mengajak siswa untuk berdoa dan & \\
& meminta salah seorang siswa memimpin doa & \\
& 3. Guru melakukan apersepsi sebagai awal & \\
komunikasi guru sebelum melaksanakan & \\
\hline
\end{tabular}




\begin{tabular}{|c|c|c|}
\hline & $\begin{array}{l}\text { pembelajaran inti. } \\
\text { 4. Guru memberikan motivasi kepada siswa } \\
\text { agar semangat dalam mengikuti } \\
\text { pembelajaran yang akan dilaksanakan } \\
\text { 5. Siswa mendengarkan pelajaran dari guru } \\
\text { kegiatan yang akan dilakukan hari ini dan } \\
\text { apa tujuan yang akan dicapai dari kegiatan } \\
\text { tersebut dengan bahasa yang sederhana dan } \\
\text { dapat dipahami }\end{array}$ & \\
\hline & $\begin{array}{l}\text { 6. Guru melakukan kegiatan penyegaran untuk } \\
\text { membuat siswa bersemangat dengan } \\
\text { mengajak bernyanyi lagu "Hari Merdeka" }\end{array}$ & \\
\hline $\begin{array}{l}\text { Kegiatan } \\
\text { Inti }\end{array}$ & $\begin{array}{l}\text { 1. Siswa mendengarkan guru membuka } \\
\text { pelajaran dengan menyanyikan lagu Bunda } \\
\text { Piara (mengamati) } \\
\text { 2. Siswa dipersilakan mengajukan pertanyaan } \\
\text { tentang lagu dan wacana pada buku siswa } \\
\text { (menanya) } \\
\text { 3. Siswa diminta membentuk kelompok kecil } \\
\text { dan berdiskusi mengenai peristiwa masa } \\
\text { kecil (mengumpulkan informasi) } \\
\text { 4. Setiap kelompok menceritakan kembali hasil } \\
\text { diskusi mereka tentang peristiwa masa kecil } \\
\text { (mengkomunikasikan) dan menuliskan cerita } \\
\text { tentang diri/ personal dengan EYD yang } \\
\text { benar. } \\
\text { 5. Siswa dibimbing untuk menyimpulkan hasil } \\
\text { presentasi tiap kelompok } \\
\text { (mengkomunikasikan) } \\
\text { 6. Siswa mengamati dan mengajukan } \\
\text { pertanyaan mengenai gambar burung garuda } \\
\text { pada buku siswa (mengamati dan menanya) }\end{array}$ & $\begin{array}{c}145 \\
\text { menit }\end{array}$ \\
\hline
\end{tabular}




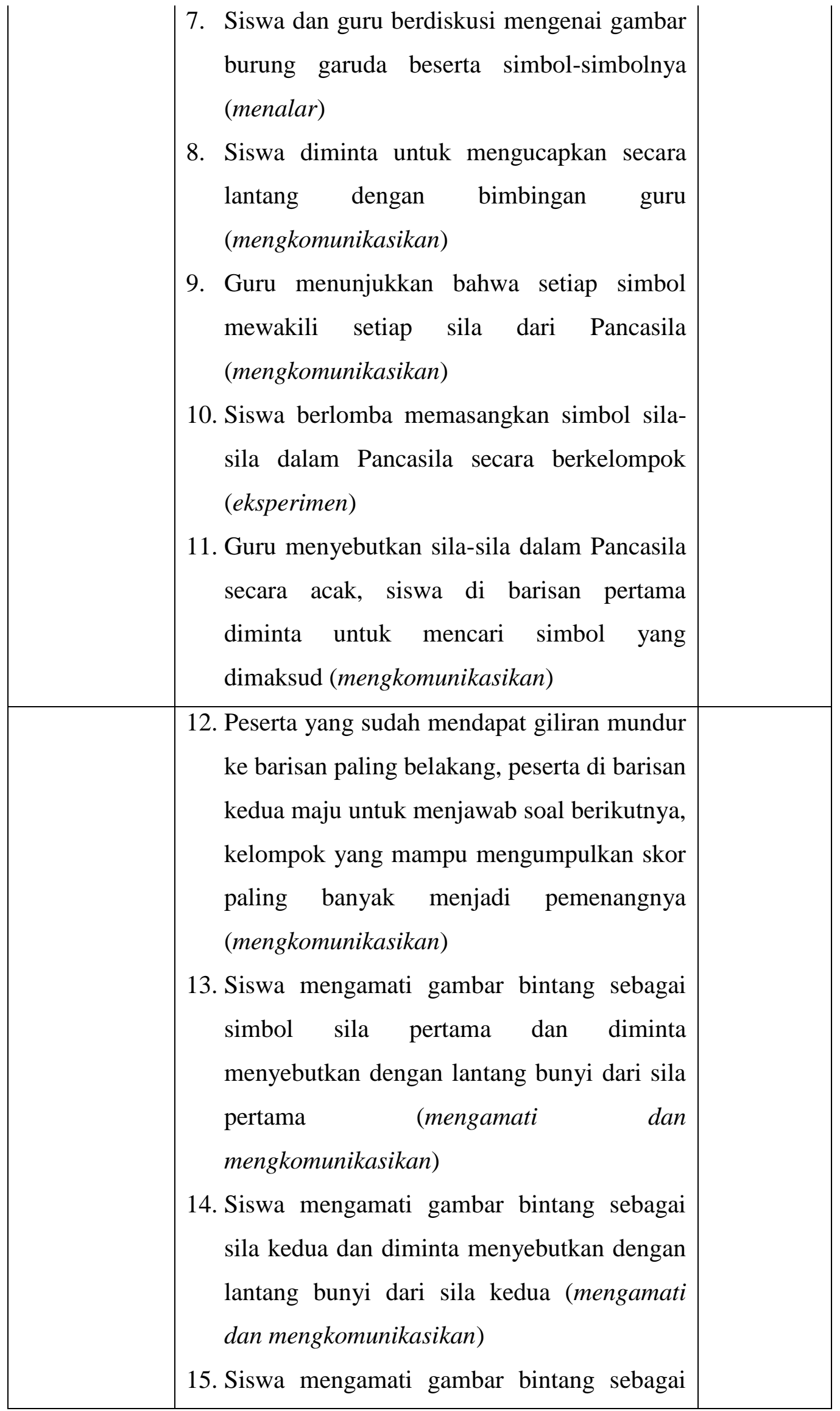




\begin{tabular}{|c|}
\hline $\begin{array}{l}\text { sila ketiga dan diminta menyebutkan dengan } \\
\text { lantang bunyi dari sila ketiga } \\
\text { dan seterusnya (mengamati dan } \\
\text { mengkomunikasikan). } \\
\text { 16. Siswa menampilkan perilaku di sekitar } \\
\text { sekolah yang sesuai dengan sila Pancasila } \\
\text { (mengkomunikasikan) } \\
\text { 17. Siswa mendengarkan guru menyanyikan } \\
\text { lagu Hari Merdeka (mengamati) } \\
\text { 18. Siswa dibimbing oleh guru untuk } \\
\text { menyanyikan lagu Hari } \\
\text { (mengkomunikasikan) } \\
\text { 19. Siswa mengajukan pertanyaan seputar lagu } \\
\text { Hari Merdeka (menanya) } \\
\text { 20. Siswa membandingkan lagu yang diiringi } \\
\text { alat music dan yang dibacakan syairnya } \\
\text { (menalar) } \\
\text { 21. Siswa menyebutkan alat-alat } \\
\text { yang mereka ketahui (mengkomunikasikan) } \\
\text { 22. Guru menjelaskan tentang alat musik ritsmis } \\
\text { ritmis (mengamati) Siswa memilih kartu bergambar alat musik } \\
\text { (molkan informasi) }\end{array}$ \\
\hline $\begin{array}{l}\text { 24. Siswa diminta untuk menyanyikan kembali } \\
\text { lagu Hari Merdeka (mengkomunikasikan) } \\
\text { 25. Guru menjelaskan tanda berirama dua pada } \\
\text { musik (mengumpulkan informasi) } \\
\text { 26. Siswa mempraktikkan lagu Hari Merdeka } \\
\text { melalui penggunaan alat musik. Alat musik } \\
\text { dapat diganti dengan menggunakan peralatan } \\
\text { dapur seperti Panci, ember, dan botol kaca } \\
\text { (eksperimen) }\end{array}$ \\
\hline
\end{tabular}




\begin{tabular}{|c|c|c|}
\hline & $\begin{array}{l}\text { 27. Bagi siswa menjadi dua kelompok. Satu } \\
\text { kelompok diminta menyanyikan lagu Hari } \\
\text { Merdeka, kelompok lainnya mengiringi } \\
\text { dengan alat musik (mengkomunikasikan). } \\
\text { Lakukan hal tersebut diatas secara bergiliran. }\end{array}$ & \\
\hline Penutup & $\begin{array}{l}\text { Guru menanyakan kepada siswa tentang materi } \\
\text { yang belum dipelajari. Dengan arahan guru } \\
\text { siswa melakukan refleksi dari kegiatan yang } \\
\text { sudah dilakukan. } \\
\text { Guru mengajak siswa berdoa sebelum } \\
\text { mengakhiri pelajaran dan meminta salah seorang } \\
\text { siswa memimpin doa. }\end{array}$ & 15 menit \\
\hline
\end{tabular}

\section{SIMPULAN}

Keberhasilan pembelajaran akan menjadi efektif bergantung dari berbagai faktor. Salah satunya adalah bagaimana seorang guru dapat mengemas pendekatan pembelajaran yang tepat. Implementasi kurikulum 2013, mengisyaratkan bahwa strategi pembelajaran harus diarahkan untuk memfasilitasi pencapaian kompetensi yang telah dirancang dalam dokumen, kurikulum agar setiap individu mampu menjadi pembelajar mandiri sepanjang hayat, dan yang pada gilirannya mereka menjadi komponen penting untuk mewujudkan masyarakat belajar. Kualitas lain yang dikembangkan kurikulum dan harus terealisasikan dalam proses pembelajaran antara lain kreativitas, kemandirian, kerja sama, solidaritas, kepemimpinan, empati, toleransi dan kecakapan hidup peserta didik guna membentuk watak serta meningkatkan peradaban dan martabat bangsa.

Untuk mencapai kualitas yang telah dirancang dalam dokumen kurikulum kegiatan pembelajaran perlu menggunakan prinsip yang : (1) berpusat pada peserta didik, (2) mengembangkan kreativitas peserta didik, (3) menciptakan kondisi menyenangkan dan menantang, (4) bermuatan nilai, etika, estetika, logika dan kinestetika, dan (5) menyediakan pengalaman belajar yang beragam melalui penerapan berbagai strategi dan metode pembelajaran yang menyenangkan, kontekstual, efektif, efisien dan bermakna. 


\section{DAFTAR PUSTAKA}

Anonimous. 2013. Bahan TOT Kurikulum 2013. Universitas Terbuka. Jakarta. Biggs and Ross Telfer. 1987. The process learning.

Anonimous. 2014. Materi Pelatihan Guru Implementasi Kurikulum 2014. Kemendikbud.

Mulyasa. 2005. Implementasi Kurikulum 2014 Panduan Kurikulum KBK. PT. Remaja Rosdakarya. Bandung.

Mulyasa. 2007. Kurikulum Tingkat Satuan Pendidkan. Rosdakarya. Bandung.

Muslimin, Ibrahim dkk. 2000. Pembelajaran Kooperatif. Surabaya. UNESA

Nanang Hanifah dan Cucu Suhana. 2009. Konsep Strategi Pembelajaran. PT. Refika Aditama. Bandung.

Ngainun Naim. 2009. Menjadi Guru Inspiratif. Pustaka Pelajar. Yogyakarta

Peraturan Menteri Pendidikan dan Kebudayaan Nomor 54 Tahun 2013 tentang Standar Kompetensi Lulusan Pendidikan Dasar dan Menengah.

Peraturan Menteri Pendidikan dan Kebudayaan Nomor 65 Tahun 2013 tentang Standar Proses Pendidikan Dasar dan Menengah.

Peraturan Menteri Pendidikan dan Kebudayaan Nomor 66 Tahun 2013 tentang Standar Penilaian Pendidikan

Peraturan Menteri Pendidikan dan Kebudayaan Nomor 57 Tahun 2013 tentang Kurikulum 2013 Sekolah Dasar/ Madrasah Ibtidaiyah

Peraturan Menteri Pendidikan dan Kebudayaan Nomor 58 Tahun 2014 tentang Kurikulum 2013 Sekolah Dasar/ Madrasah Ibtidaiyah

Peraturan Menteri Pendidikan dan Kebudayaan Nomor 59 Tahun 2014 tentang Kurikulum 2013 Sekolah Dasar/ Madrasah Ibtidaiyah

Oemar Hamalik. 2003. Proses Belajar Mengajar Cet. 2. Jakarta : Bumi Aksara.

Irianto. 2011. Mendesain Model Pembelajaran Inovatif-Progesif. Cet.4 Jakarta: Prenada Media Group.

Wina Sanjaya. 2005. Pembelajaran dan Implementasi Kurikulum Berbasis Kompetensi. Jakarta : Prenada.

Wina Sanjaya. 2006. Srategi pembelajaran Berorientasi pada Standar Proses Pendidikan. Prenada Media. Jakarta. 